\title{
The last dinosaurs of Brazil: The Bauru Group and its implications for the end-Cretaceous mass extinction
}

\author{
STEPHEN L. BRUSATTE ${ }^{1}$, CARLOS R.A. CANDEIRO ${ }^{2}$ AND FELIPE M. SIMBRAS $^{3}$ \\ ${ }^{1}$ School of GeoSciences, University of Edinburgh, Grant Institute, James Hutton Road, EH9 3FE, Edinburgh, United Kingdom \\ ${ }^{2}$ Laboratório de Paleontologia e Evolução, Curso de Geologia, Campus Aparecida de Goiânia, Universidade Federal \\ de Goiás, Rua Mucuri, s/n, Área 03, St. Conde dos Arcos, 74968-755 Aparecida de Goiânia, GO, Brazil \\ ${ }^{3}$ Petróleo Brasileiro S.A. (PETROBRAS), Av. República do Chile, 330, $17^{\circ}$ andar, Centro, 20031-170 Rio de Janeiro, RJ, Brazil
}

Manuscript received on December 12, 2016; accepted for publication on March 24, 2017

\begin{abstract}
The non-avian dinosaurs died out at the end of the Cretaceous, $\sim 66$ million years ago, after an asteroid impact. The prevailing hypothesis is that the effects of the impact suddenly killed the dinosaurs, but the poor fossil record of latest Cretaceous (Campanian-Maastrichtian) dinosaurs from outside Laurasia (and even more particularly, North America) makes it difficult to test specific extinction scenarios. Over the past few decades, a wealth of new discoveries from the Bauru Group of Brazil has revealed a unique window into the evolution of terminal Cretaceous dinosaurs from the southern continents. We review this record and demonstrate that there was a diversity of dinosaurs, of varying body sizes, diets, and ecological roles, that survived to the very end of the Cretaceous (Maastrichtian: 72-66 million years ago) in Brazil, including a core fauna of titanosaurian sauropods and abelisaurid and carcharodontosaurid theropods, along with a variety of small-to-mid-sized theropods. We argue that this pattern best fits the hypothesis that southern dinosaurs, like their northern counterparts, were still diversifying and occupying prominent roles in their ecosystems before the asteroid suddenly caused their extinction. However, this hypothesis remains to be tested with more refined paleontological and geochronological data, and we give suggestions for future work.
\end{abstract}

Key words: Brazil, Cretaceous, dinosaur, Gondwana, K-Pg boundary, mass extinction.

\section{INTRODUCTION}

Dinosaurs, along with many other vertebrate and invertebrate groups, were decimated by a mass extinction at the end of the Cretaceous Period, 66 million years ago (e.g., MacLeod et al. 1997, Archibald and Fastovsky 2004, Brusatte et al. 2015a). All of the iconic non-avian species that

Correspondence to: Stephen L. Brusatte

E-mail: stephen.brusatte@ed.ac.uk had dominated terrestrial ecosystems for over 150 million years died out, leaving only a few lineages of small flying taxa that survived into the ensuing Paleogene, which eventually re-radiated and gave rise to the birds of today. By now, it is widely recognized that a giant asteroid struck the Earth right at the end of the Cretaceous, unleashing a cocktail of heat, fire, earthquakes, tsunamis, and global darkness that would have had devastating 
effects on ecosystems worldwide and likely played a key role in the mass extinction (e.g., Alvarez et al. 1980, Schulte et al. 2010).

In regards to dinosaurs, the prevailing hypothesis is that the non-avian species died out rapidly as a result of the impact (see Brusatte et al. 2015a and references therein). But, because there were also extensive volcanic eruptions, temperature changes, and sea level fluctuations occurring in the latest Cretaceous, there is lingering doubt about whether the asteroid acted alone or whether dinosaurs may have been in something of a decline during the final $\sim 15-20$ million years of the Cretaceous (e.g., Archibald 1996). This debate persists because the fossil record of latest Cretaceous dinosaurs is incomplete and heavily biased, with only a few regions of the globe preserving an abundance of well-studied and welldated dinosaurs from the several million years before the asteroid impact. Almost all of these sites are in the northern hemisphere, chief among them the Maastrichtian Hell Creek Formation and equivalents in western North America (e.g., Hartman et al. 2002, Fastovsky and Bercovici 2016), as well as similar-aged localities in Spain (e.g., Vila et al. 2016) and Romania (e.g., CsikiSava et al. 2015, 2016b). Very little is known about the final non-avian dinosaurs of the southern continents, and this gaping hole in our knowledge makes it very difficult to conclusively test whether the dinosaur extinction was a sudden, global event or a more drawn out affair that may have proceeded at different paces in different regions.

Over the last few decades, the fossil-rich sedimentary rocks of the Upper Cretaceous levels of the Bauru Group in the Paraná Basin of Central Brazil-which were deposited in southwestern Central Gondwana-have emerged as a rare window into these last-evolving southern dinosaurs. A wealth of new discoveries reveals that a diversity of meat-eating, plant-eating, and possibly omnivorous species of varying body size ranged across the Paraná sedimentary basin during the last $\sim 15-20$ million years of the Cretaceous (latest Santonian-Maastrichtian). However, these fossils have yet to be synthesized, so their implications for understanding the end-Cretaceous extinction are still unclear. We here provide a review of the Bauru Group dinosaurs: what types are known, what time intervals they came from, and what they are starting to hint about the extinction. We argue that the current fossil record is beginning to expose a relatively diverse dinosaur fauna at the end of the Cretaceous - in the sense that several major subgroups were living alongside each other and occupying important roles in their ecosystems - which is most consistent with stable, dinosaur-dominated ecosystems that were suddenly interrupted by the asteroid impact.

\section{AGE AND GEOLOGICAL SETTING OF BRAZILIAN LATEST CRETACEOUS UNITS}

Most of the latest Cretaceous dinosaurs of Brazil are found in a series of sedimentary units that belong to the Bauru Group. Rocks of the Group crop out over an area of approximately 370, 000 square kilometers, which includes portions of six Brazilian states (São Paulo, Paraná, Mato Grosso, Mato Grosso do Sul, Minas Gerais and Goiás), as well as parts of Paraguay (Caiuá Formation) (see overview by Fernandes and Ribeiro 2015) (Figs. 1-2). The Bauru Group is the LowerUpper Cretaceous sedimentary sequence of the Paraná Basin. It predominantly consists of eolian sandstones in its Lower Cretaceous sections, and alluvial to fluvial conglomerates, sandstones, siltstones, and mudstones with subordinate lacustrine mudstones in its Upper Cretaceous sections. This package of rocks was deposited in a subsiding sedimentary basin, which developed in the central-southern South American Platform as a result of thermo-mechanical subsidence following the breakup of Gondwana and the opening of 
the southern Atlantic Ocean between the South America and Africa (Fernandes and Coimbra 1996, Fernandes and Ribeiro 2015).

The Bauru Group is subdivided into several formations and members (Fig. 1), but the stratigraphic nomenclature varies across the literature. The most commonly used terminology stems from the work of Soares et al. (1980), with some small modifications that have developed as the Bauru Group has become better studied over the last three decades. This system divides the Group into six key formations, listed here in stratigraphic order beginning with the oldest (although there is, in some cases, interfingering between the formations that suggests a more nuanced stratigraphy that may be highly variable locally): the Caiuá, Santo
Anastácio, Araçatuba, Adamantina, Presidente Prudente, and Marília formations (see discussion in Soares et al. 1980, Fernandes and Coimbra 1996, 2000, Gobbo-Rodrigues et al. 1999, Kellner and Azevedo 1999, Dias-Brito et al. 2001, Zaher et al. 2006, Paula e Silva et al. 2009, Azevedo et al. 2013, Peyerl et al. 2015, Brum et al. 2016). Additionally, there is a seventh highly localized formation, the Uberaba Formation, which crops out only in Minas Gerais and interdigitates with the Adamantina Formation (Souza 1984). Furthermore, other units may occur only in the subsurface, as shown by well $\log$ and core data. According to Paula e Silva et al. (2003, 2009), these include two main units: the Pirapozinho Formation, formed of sandstones and mudstones in lateral position to the Lower
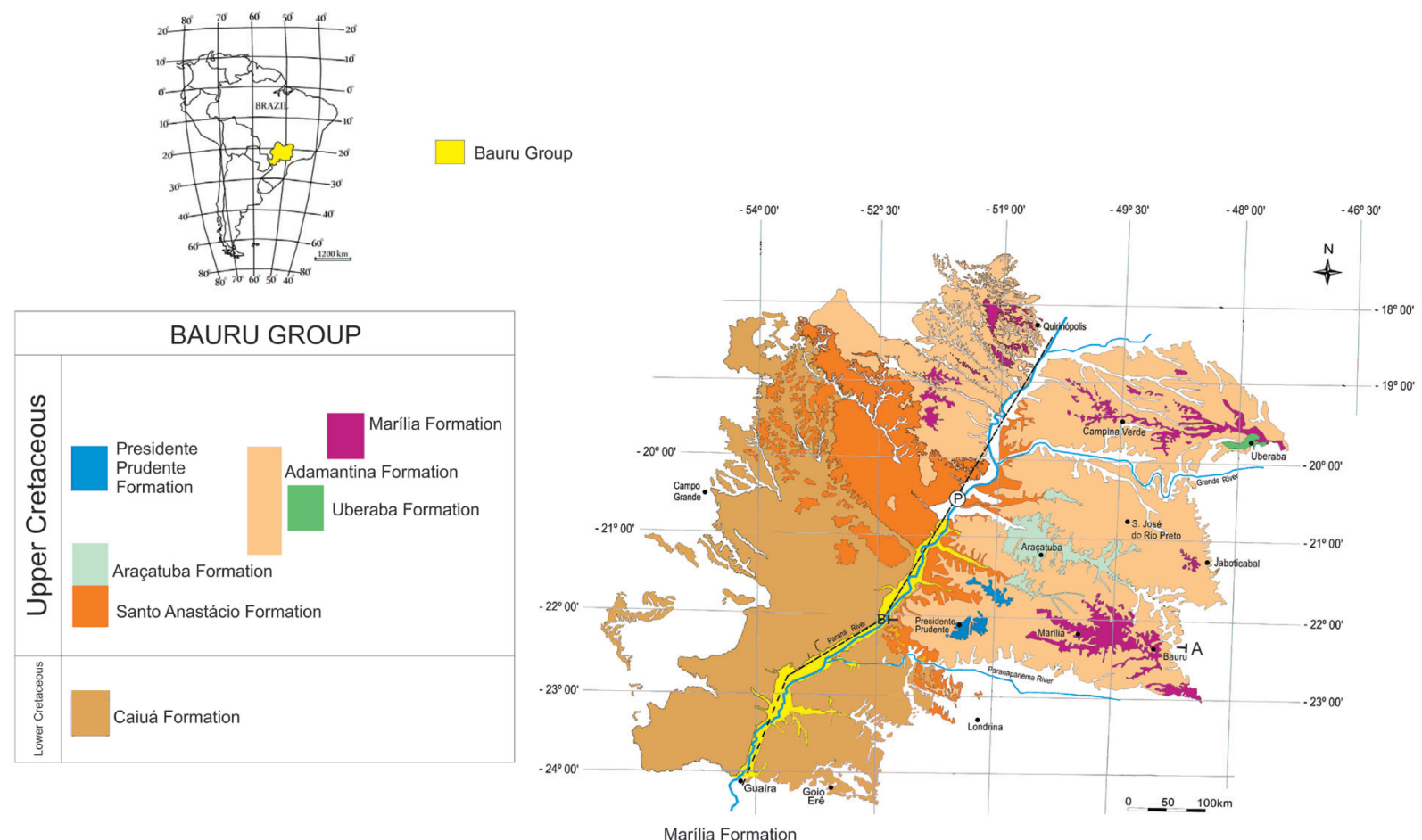

b

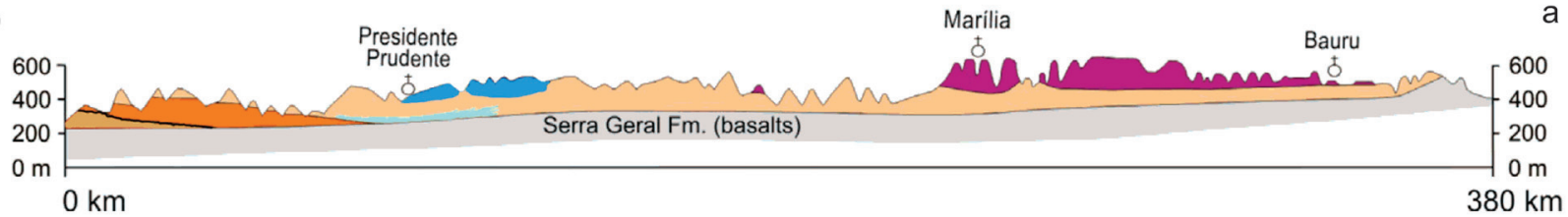

Figure 1 - Geological map of the Bauru Group with regional section a-b (modified from Fernandes and Ribeiro 2015). Figure by F. Simbras. 


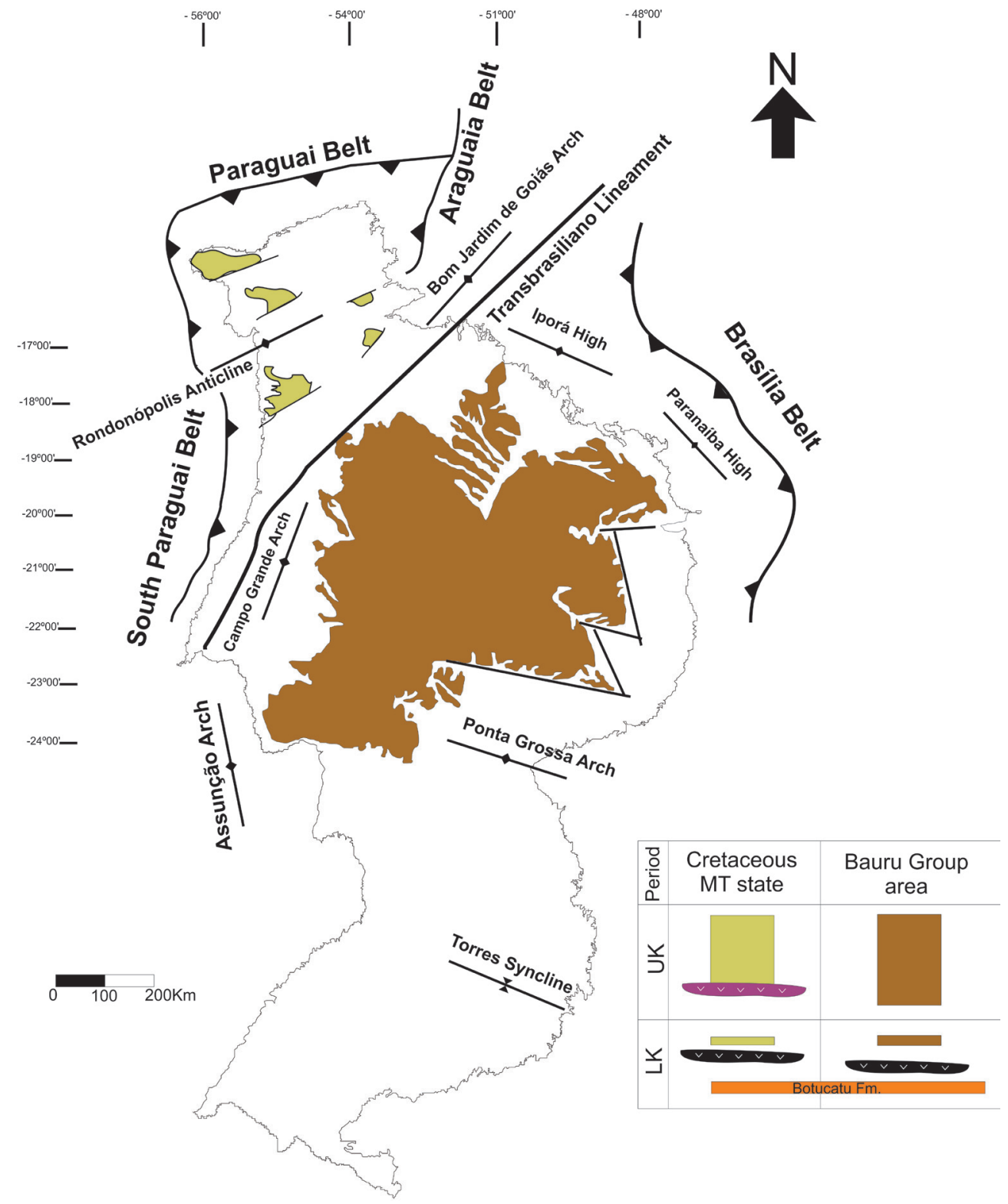

Figure 2 - Geotectonic map of the Paraná Basin showing the Cretaceous area of the Bauru Group (brown) and the other Cretaceous areas restricted to the Mato Grosso state (yellow), following Coimbra (1991). The black volcanic rocks are related to the basalts of the Serra Geral Formation. The violet volcanic rocks are related to the alkaline basalts of the Paredão Grande Formation. Figure by F. Simbras.

Cretaceous Caiuá sandstones in southwestern São Paulo state, and the Birigüi Formation, composed of sandstones and conglomerates below the lacustrine facies of the Araçatuba Formation.

It is widely recognized that the majority of the Bauru Group, with the exception of the Caiuá Formation, is Late Cretaceous in age, but there is uncertainty about the precise ages of the individual units (Fig. 1). Age assessments have been based on a complex interplay of stratigraphical correlations, vertebrate and microfossil biostratigraphy, and magnetostratigraphy. Unfortunately, there are no radioisotopic dates that constrain the ages of the upper portions of the Bauru Group, which 
makes it difficult to determine how much of the formation is genuinely latest Cretaceous (Campanian-Maastrichtian) in age. This, in turn, precludes a more robust timeline of local dinosaur evolution during the latest Cretaceous and makes it impossible, at present, to determine how close to the K-Pg boundary (which has not yet been identified in the Bauru Group) the Brazilian dinosaur record extends.

A Cretaceous age for the Bauru Group was originally proposed by Friedrich von Huene, who studied some of the first dinosaur remains collected from the basin and recognized that they belonged to sauropods characteristic of the 'Senonian', which at that time referred to an interval today regarded as spanning the middle-Late Cretaceous (Huene 1927, 1929, 1939). Recent works on the geology of the Bauru Group have upheld this view. For example, the important stratigraphic revision of the Bauru sediments published by Fernandes and Coimbra (1996) considered the rocks of the basin to have formed between the Santonian and Maastrichtian stages of the Late Cretaceous, largely based on the vertebrate fossils of the Adamantina and Marília formations, which belong to characteristic latest Cretaceous Gondwanan taxa such as abelisaurids and aeolosaurin sauropods.

More recently, a critical clue from magnetostratigraphy has helped refine when in the middle-Late Cretaceous some of the Bauru Group rocks must have formed. Tamrat et al. (2002) found that the Uberaba and Marília formations were of reversed polarity, which means they cannot be older than ca. 83 million years ago, approximately the boundary between the Santonian and Campanian. This is because a large swathe of the preceding Early-mid Cretaceous, from about 121-83 million years ago, was a long-stand of normal polarity (the so-called Cretaceous Normal Superchron or Cretaceous Quiet Zone: Cande and Kent 1995, He et al. 2008). The combination of reversed magnetic polarity and characteristic latest
Cretaceous dinosaurs in these units can only mean that these fossil-bearing rocks of the Uberaba and Marília formations formed sometime during the very latest Santonian-Maastrichtian. By extension, portions of the Adamantina Formation correlative with the Uberaba Formation, and the portions of the Presidente Prudente Formation that sit above or interfinger with the Adamantina Formation, must also be latest Santonian-Maastrichtian in age.

Magnetostratigraphy also helps define which portions of the Bauru Group are not Late Cretaceous in age. In particular, magnetostratigraphic data indicates that the Caiuá Formation was deposited in the Early Cretaceous, between about 130-120 million years ago (Ernesto et al. 2006, Batezelli 2010). This confirms the initial stratigraphic interpretations of Soares et al. (1980), whose outcrop studies showed an unconformity between the Caiuá Formation below and the Santo Anastácio Formation above, which reflects the breakup of the South Atlantic Ocean in the Santos Basin. This unconformity has also been identified in well logs by Paula e Silva et al. (2009) in the same stratigraphic position, between the Pirapozinho Foramation (which is the subsurface lateral equivalent to the Caiuá Formation) and the Santo Anastácio Formation. These magnetostratigraphic and stratigraphic findings do not corroborate Fernandes and Coimbra's (1996, 2000) argument that there is lateral correlation between all units of the Bauru Group, including the Caiuá Formation, which would make this latter formation Late Cretaceous in age.

Within the unequivocally latest Cretaceous portion of the Bauru Group, there are three fossiliferous formations that may date, in part, to the Maastrichtian, the final stage of Cretaceous (Fig. 1). Therefore, these formations may yield some of the last-evolving dinosaurs in South America. We briefly review the ages and depositional environments of these formations here. 
The Adamantina Formation comprises sandstones with rare conglomerates and mudstones, formed in channels, thin overbank floods, and ponds. There are also some desert lithologies, which decrease upwards through the formation. The lacustrine and fluvial clays and sandstones begin to appear in the middle-to-upper part of the unit, which were deposited in warm and humid conditions (Soares et al. 1980, Suguio and Barcelos 1983, Fernandes and Coimbra 1996, 2000, Castro et al. 1999). (It is also worth noting here that another unit often considered to be a formationthe Uberaba Formation, which interfingers with the Adamantina Formation-is composed of limestones, sandstones, and conglomerates, often cemented by calcite with volcaniclastic sediments [Hasui 1969, Barcelos 1984]).

It is often stated in the literature that the Adamantina Formation is Turonian-Santonian in age, based on its ostracod and charophyte assemblages (Dias-Brito et al. 2001). However, vertebrate biostratigraphic data suggests that parts of the formation, particularly its upper interval, may be younger. Santucci and Bertini (2001) identified specimens of the titanosaurian sauropod Aeolosaurus in the Adamantina Formation, and because this dinosaur genus is known from late Campanian-early Maastrichtian aged rocks in Argentina, they proposed a similar age for the upper part of the Adamantina Formation in Brazil. A follow-up study by Martinelli et al. (2011) cast doubt on the referral of the Adamantina fossils to Aeolosaurus, but subsequently Santucci and Arruda-Campos (2011) described a partially articulated skeleton from the formation that they identified as belonging to Aeolosaurus, which they described as a new species of the genus ( $A$. maximus). The lower-level taxonomic affinities of these specimens is the subject of ongoing work, and it may be that none of them belong to the genus Aeolosaurus proper (Simbras et al., unpublished data). However, it is widely recognized that they are all very closely related sauropods in a restricted subclade, Aeolosaurini, regardless of what genera they are assigned to. Therefore, if Aeolosaurus (or Aeolosaurini) is a good index taxon that ranged across South America at roughly the same time, this would indicate that the upper part of the Adamantina Formation dates to sometime close to the Campanian-Maastrichtian boundary. However, terrestrial vertebrate fossils may not always be good biostratigraphic indicators (Rayfield et al. 2009), so this line of inference should be treated with caution. With that said, it is also worth noting that Gobbo-Rodrigues et al. (1999) assigned a Campanian-Maastrichtian age to the lower portion of the Adamantina Formation based on its ostracod fauna, which if correct would constrain the upper part of the formation to a Campanian or younger age, consistent with the arguments based on Aeolosaurus.

The Presidente Prudente Formation consists of sandstones and mudstones deposited in a shallow meandering fluvial system, representing channel and overbank settings (Fernandes and Coimbra 2000, Simbras 2009). There has been little work on the geochronology of the formation, but it is often considered to be Campanian-Maastrichtian in the literature (e.g., Azevedo et al. 2013, Bandeira et al. 2016). This is largely based on lithological correlations that indicate lateral gradational contacts between the Presidente Prudente Formation and the Adamantina Formation, whose age has been determined as latest Santonian-Maastrichtian through more intensive study (see above) (Zaher et al. 2006, Simbras 2009). Furthermore, Azevedo and Simbras (2009) described an aeolosaurin caudal vertebra from the Presidente Prudente Formation; if aeolosaurins are reliable biostratigraphic indicators (see above), then this would support a CampanianMaastrichtian age of the formation.

It is also worth noting that Gobbo-Rodrigues et al. (1999) assigned a Campanian - Maastrichtian age to mudstones near Pirapozinho municipality 


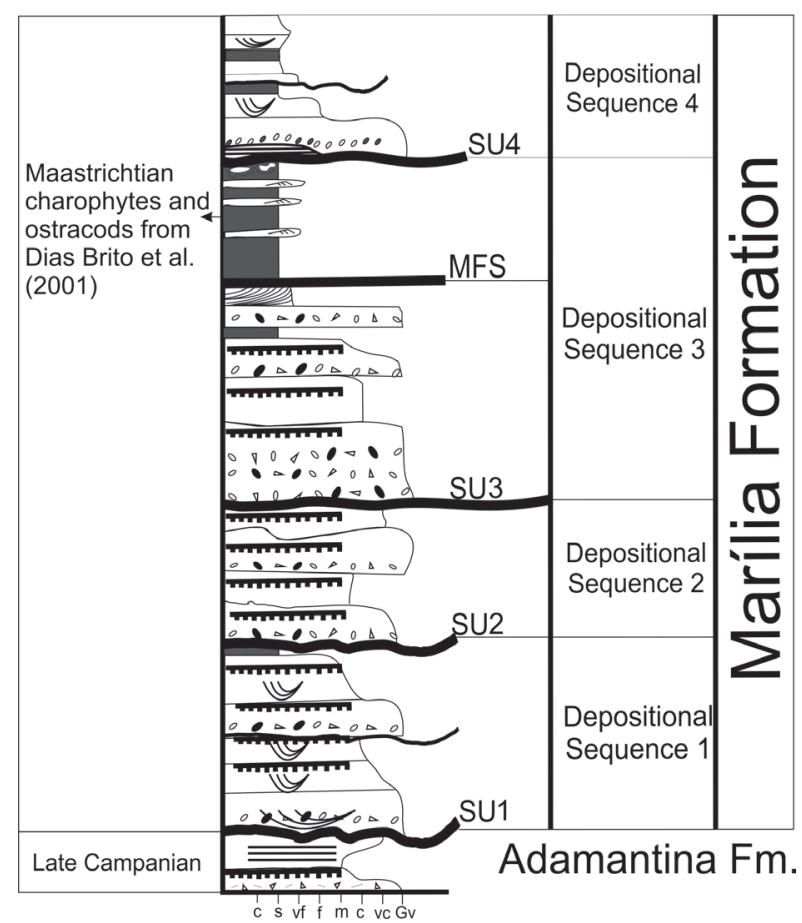

Figure 3 - Sequence stratigraphic framework of the top of the Adamantina Formation and the Marília Formation. Maxakalisaurus is from the top of the Adamatina Formation and the major Marília sauropods are from the base of the Marília Formation. There is some sauropod material from above the SU4, from the Gurinhatã-Campina Verde Road in Triângulo Mineiro region. The location of the microfossils dated by DiasBrito et al. (2001) is indicated. SU=subaerial unconformity; $\mathrm{MFS}=$ maximum flooding surface. Figure by F. Simbras.

based on the presence of Limnocytheridae ostracods. These authors considered these rocks to belong to the Araçatuba Formation, although the rocks had previously been considered as belonging to the Adamantina Formation by Soares et al. (1980). However, this area was recently mapped as the Presidente Prudente Formation by Fernandes and Coimbra (2000). Therefore, the ostracods lend support for the Campanian-Maastrichtian age of the Presidente Prudente Formation.

The Marília Formation is dominated by sandstones and conglomerates, which are often cemented by carbonate (limestone) and contain carbonate concretions (Soares et al. 1980, Fulfaro and Barcelos 1991). For this reason, they are sometimes mined locally as a source of lime for agricultural fertilizer. These rocks were formed in alluvial fans associated with the uplift of the eastern border of the Bauru sedimentary basin (Riccomini 1997). The coarse-grained alluvial sediments were later reactivated and redeposited by an anastomosing fluvial system rich in calcareous minerals (Barcelos and Suguio 1987). The age of the formation is usually considered to be Maastrichtian, based on its charophyte and ostracod assemblages (GobboRodrigues et al. 1999, Dias-Brito et al. 2001), vertebrate fossils (Fernandes and Coimbra 1996, 2000), and the fact that it stratigraphically overlies the latest Santonian-Maastrichtian Adamantina Formation (Zaher et al. 2006).

Recent work on the sequence stratigraphy of the Marília Formation is providing additional insight into the age of its dinosaur fossils (Fig. 3). The Formation has four depositional sequences, and the mudstones that provided the microfossils dated by Dias-Brito et al. (2001) come from the third sequence. Dinosaur fossils extend into the fourth, and youngest, sequence. These dinosaursparticularly those from the Gurinhatã municipality, are likely the closest dinosaurs to the K-Pg boundary in the Bauru Group, although it is still unclear exactly how close to the boundary they extend (for more discussion, see Moreira et al. 2007).

\section{LATEST CRETACEOUS DINOSAURS FROM BRAZIL}

There is a growing record of dinosaurs and other vertebrate fossils from the unequivocally latest Cretaceous (latest Santonian-Maastrichtian) aged formations of the Bauru Group (Figs. 4-5). Many of these specimens are isolated teeth and vertebrae (Bertini et al. 1993, Candeiro et al. 2006a, b), but over the past two decades several more complete specimens, including associated partial skeletons, have been found (see below). We here focus on dinosaurs and summarize the most important aspects of their fossil record. This 
is not an exhaustive survey, but a chronicle of the most salient fossils that give insight into how the major dinosaur groups were evolving during the end-Cretaceous. For more exhaustive reviews of the Brazilian dinosaur record as a whole, please consult Kellner and Campos (2002) and Bittencourt and Langer (2011).

Adamantina Formation: A number of theropod and sauropod fossils have been reported from the Adamantina Formation.

The vast majority of the theropod remains found in this unit can be assigned to Abelisauridae, one of the main groups of mid-to-large-sized predatory dinosaurs that ranged across Gondwana during the middle-Late Cretaceous, often filling niches at or near the top of the food chain. Most of these specimens are isolated teeth that do not give much insight into the phylogenetic relationships or paleobiology of these carnivores (e.g., Bertini 1996, Candeiro et al. 2004, Candeiro and Rich 2010). However, a few specimens preserve portions of the skeleton. Bertini (1996) described a fragment of a right premaxilla and Brum et al. (2016) described a fragmentary left ilium and distal portion of a right femur. These latter specimens were estimated to belong to separate individuals that were each approximately 2-3 meters long in total body length, making them relatively small abelisaurids compared to giants such as Carnotaurus that were approximately 8 meters long (Grillo and Delcourt 2017) and had body masses in excess of 1.5 tons (Benson et al. 2014).

There is one Brazilian abelisaurid, however, that was considerably larger. Kellner and Campos (2002) described Pycnonemosaurus based on an associated collection of teeth, caudal vertebrae, and parts of the pelvis and hindlimb. These bones were discovered in terrestrial conglomerates at the Fazenda Roncador (=Jangada Roncador) locality in the Cambambe Basin, a Late Cretaceous graben in the Paraná Basin of Mato Grosso State. The identity and correlations of these conglomerates are somewhat uncertain. According to Coimbra (1991), these conglomerates, which are at the base of the Cretaceous sedimentary rocks of the Cambambe Basin, belong to the Ribeirão Boiadeiro Formation. This unit is covered by the conglomerates and sandstones of the Cambambe Formation. The lower sequences of the Cambambe Formation in the Morro do Cambambe area yielded an aeolosaurin specimen studied by Franco-Rosas et al. (2004). Therefore, based on biostratigraphic correlations, the Cambambe Formation should be considered correlative to the upper interval of the Adamantina Formation, to the Presidente Prudente Formation, and also to the basal-most interval of the Marília Formation, which all seem to be apparently equivalent in age. Sometimes in the literature, the Cretaceous rocks of Mato Grosso state are said to be correlated with the Adamantina Formation based on the aeolosaurin specimen (e.g., Candeiro et al. 2012b), but the correlations to the similaraged Presidente Prudente and Marília formations are not explicitly mentioned.

Grillo and Delcourt (2017) used bone scaling equations to estimate the body length of Pycnonemosaurus at 8.9 meters, which would make it the largest known abelisaurid. It is possible that this size estimate may be overinflated, because the bones used to calculate it are fragmentary, but what is clear is that Pycnonemosaurus is among the largest abelisaurids yet found and would have been a top-of-the-food-chain predator probably quite similar to Carnotaurus in its size and behaviors.

One peculiar type of non-avian theropod was reported from the Adamantina Formation by Candeiro et al. (2012b). These authors described a small dorsal vertebra, with a centrum that was only approximately one centimeter long anteroposteriorly in lateral view, as belonging to a unenlagiine (Fig. 5f). These highly derived, birdlike theropods are an apparently endemic southern group of dromaeosaurids, which lived during the middle-Late Cretaceous and include some 


\section{a - Baurutitan britoi}

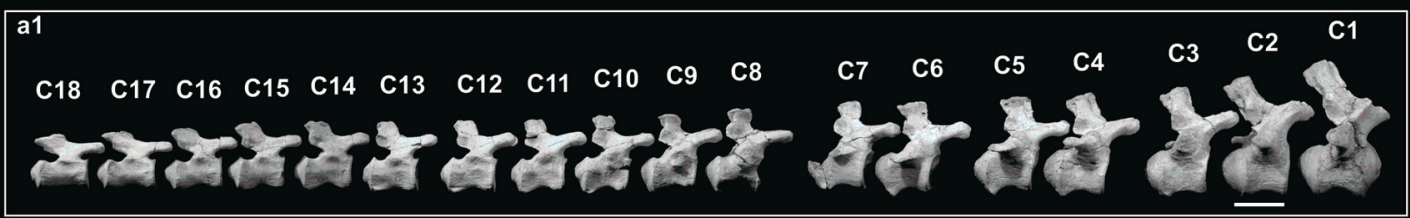
".
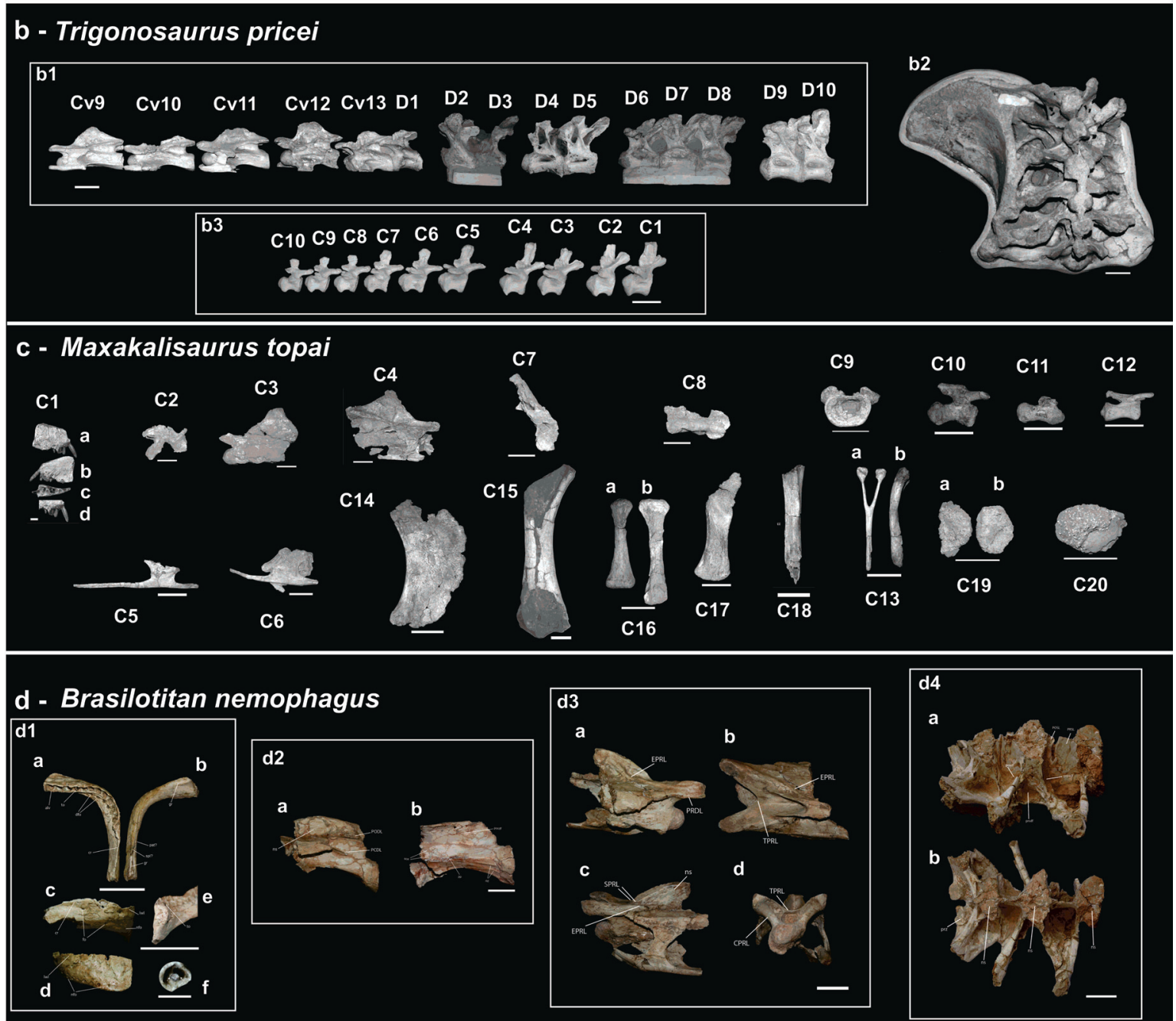

e - Austroposeidon magnificus

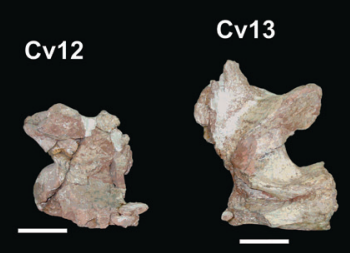

D1

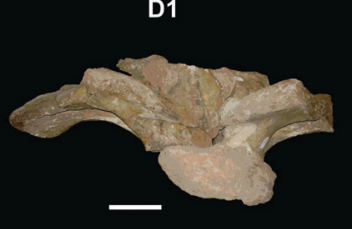

D2

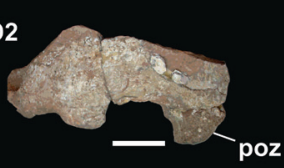

D5

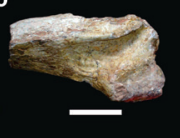

D6

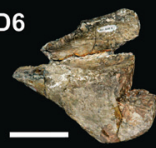

D7

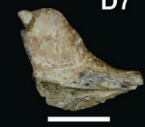

S

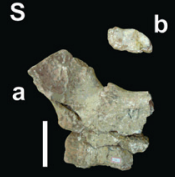


Figure 4 - Holotypic material of five sauropod species from the Bauru Group. a - Baurutitan britoi Kellner et al. 2005, where $\mathrm{a} 1$ and $\mathrm{a} 2$ are the caudal and the haemal arch sequences in right lateral views (scale $=10 \mathrm{~cm})$. $\mathbf{b}-$ Trigonosaurus pricei Campos et al. 2005, where b1 is the cervical and dorsal elements preserved; b2 is the sacrum, and b3 is the caudal sequence preserved $($ scales $=10 \mathrm{~cm}) . \mathbf{c}-$ Maxakalisaurus topai Kellner et al. 2006, where: c1 - right maxilla in lateral (a), medial (b), occlusal (c) and tooth detail $(\mathbf{d})$ views $($ scale $=1 \mathrm{~cm})$; $\mathrm{c} 2$ - third cervical vertebra in right lateral view; $\mathrm{c} 3-$ Mid-cervical vertebra $\left(7^{\text {th }}\right.$ ?) in left lateral view; c4 - Mid-posterior cervical vertebra $\left(10^{\text {th }}\right.$ ?) in right lateral view; c5 - cervical rib of mid-posterior cervical vertebra in lateral view; c6 - cervical rib of mid-cervical vertebra in lateral view; c7 - anterior dorsal vertebra ( $3^{\text {rd}}$ ?) in right lateral view; c8 - right sacral rib in anterior view; c9 - anterior caudal vertebra in anterior view; c10 - mid-caudal vertebra in right lateral view; c11 and c12 - posterior caudal vertebra in right lateral view; c13 - Haemal arch in posterior (a) and left lateral (b) views; c14 - sternal plate; c15 - right humerus in anterior view; c16 - Metacarpals IV (a) and II (b) in anterior view; c17 - right ischium in lateral view; c18 - left fibula in anterior view; c19 (a) and (b)- two osteoderms in internal view ; c20 - osteoderm in external view $(\mathrm{c} 2-\mathrm{c} 20$ scales $=10 \mathrm{~cm})$. Abbreviations of d: cpol, centropostzygapophyseal lamina; cprl, centroprezygapophyseal lamina; eprl, epipophyseal-prezygapophyseal lamina; pcdl, posterior centrodiapophyseal lamina; pcpl, posterior centroparapophyseal lamina; podl, postzygodiapophyseal lamina; posl, postspinal lamina; prdl, prezygodiapophyseal lamina; prsl, prespinal lamina; spd, spinodiapophyseal lamina; spol, spinopostzygapophyseal lamina; sprl, spinoprezygapophyseal lamina; tpol, intrapostzygapophyseal lamina; tprl, intraprezygapophyseal lamina. More details in Machado et al. (2013). Figure by F. Simbras.

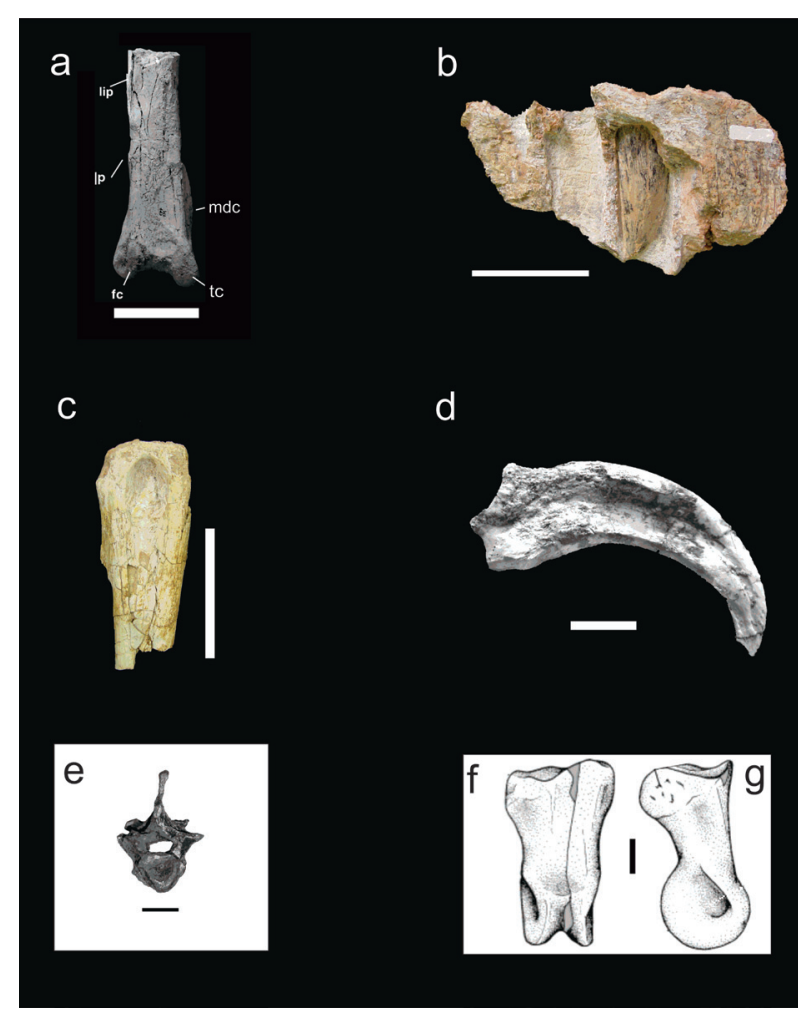

Figure 5 - Montage of bones of theropods from the Upper Cretaceous Bauru Group of Brazil. (a) Abelisauroidea indet. left femur in posterior view; (b) Carcharodontosauridae indet. right maxilla in lateral view; (c) Coelurosauria indet. right fíbula in medial view; (d) Maniraptora indet. ungual phalanx in lateral view; (e) Unenlagiidae indet. dorsal vertebra in anterior view; (f-g) Aves indet. isolated pedal phalanx of left digit II in dorsal (left) and lateral (right) views. aA, from Novas et al. (2008); b-c, from Azevedo et al. (2013); d, from Novas et al. (2005); e, from Candeiro et al. (2012b); f-g, from Candeiro et al. (2012a); Scale bar: $a-b=100 \mathrm{~mm}$; $c$ and $\mathrm{e}=50 \mathrm{~mm}$; , $\mathrm{f}-\mathrm{g}=$ $10 \mathrm{~mm}$. Figure by F. Simbras. of the largest (Austroraptor) and also smallest (Buitreraptor, Rahonavis) 'raptor' dinosaurs (e.g., Turner et al. 2012). Unenlagiines are primitive dromaeosaurids, fairly closely related to iconic species of active, dynamic, feathered predators like Velociraptor and Deinonychus. The diets and behaviors of unenlagiines, however, are not clear and it is possible that they were not obligatory carnivores but had a more varied diet.

Numerous sauropod fossils have been described from the Adamantina Formation, including some reasonably complete skeletons and other associated remains that have been named as a suite of new species (Fig. 4). Many of these belong to Aeolosaurini, a subgroup of derived titanosaurian sauropods currently known only from the Late Cretaceous of South America. Aeolosaurins from the Adamantina Formation include Gondwanatitan, described from a set of bones that includes parts of the neck, back, sacrum, tail, pectoral and pelvic girdles, and fore and hind limbs (Kellner and Azevedo 1999); Maxakalisaurus, represented by an incomplete disarticulated holotype skeleton (Kellner et al. 2006) and a partial right dentary and isolated teeth (França et al. 2016) (although see Bandeira et al. 2016 for an alternative phylogenetic placement) (Fig. 4a); and Aeolosaurus maximus, based on an articulated skeleton that preserves portions of the neck, tail, and fore and hind limbs 
(Santucci and Arruda-Campos 2011). Compared to well-known sauropod giants such as Brachiosaurus and Diplodocus, as well as celebrated titanosaurs like Argentinosaurus and Dreadnoughtus, the aeolosaurins were relatively small in stature. Rinconsaurus, one of the few aeolosaurins or close relatives known from long bones that can be used to estimate body mass, tipped the scales at around 4 tons (Benson et al. 2014), and was probably around 11 meters in total body length (Calvo and GonzálesRiga 2003). However, not all aeolosaurins may have been so small: Santucci and Arruda-Campos (2011) named the species Aeolosaurus maximus in homage to its large size, and their illustrations depict a total body length estimate of 14-15 meters. Regardless, what is clear is that aeolosaurins may not have been as large as stereotypical sauropods, but were still massive, bulk-feeding herbivores.

There are also two other named titanosaurs from the Adamantina Formation, whose phylogenetic relationships are less certain. The first is Adamantisaurus, described by Santucci and Bertini (2006) based on a series of six articulated anterior caudal vertebrae and two chevrons. The second is Brasilotitan, which Machado et al. (2013a) named from a specimen that includes a dentary, cervical and sacral vertebrae, an ungual, and parts of the pelvis (Fig. 4b). It is possible that these sauropods also belong to Aeolosaurini, or they may represent other, more distantly related titanosaurs.

As a quick note, it is important to point out that some of these sauropods may not actually come from the Adamantina Formation as described, but from the Presidente Prudente Formation (as defined by Fernandes and Coimbra 2000), due to new geological mapping that has refined lithostratigraphic boundaries and regional correlations. This will be clarified by future geological fieldwork. It is also possible that the lower-level systematics and phylogenetic placements of some of these sauropods will change, pending ongoing work by one of us (Simbras).

Presidente Prudente Formation: As with the Adamantina Formation, most dinosaur records from the Presidente Prudente Formation consist of isolated teeth (e.g., Candeiro et al. 2004, Furtado et al. 2013, Alves et al. 2016). These specimens record the presence of two major theropod groups: abelisaurids and carcharodontosaurids. Carcharodontosaurids were a clade of large-bodied theropods closely related to Allosaurus, which ranged across much of the globe during their early history in the Early-middle Cretaceous but then apparently became restricted to the southern hemisphere during the latest Cretaceous, where some of them grew to colossal sizes that rivaled T. rex and assumed top-predator status in many ecosystems (e.g., Brusatte and Sereno 2008, CsikiSava et al. 2016a).

More recent discoveries of skeletal material corroborate the identification of abelisaurids and carcharodontosaurids in this formation (Fig. 5). Azevedo et al. (2013) described a fragment of a left ilium that can be referred to Abelisauridae, along with a partial right maxilla that belongs to a carcharodontosaurid (Fig. 5b-c). This latter specimen was the first non-dental record of a carcharodontosaurid from Brazil, and its measurements indicate that it belonged to an animal with a skull ca. 80 centimeters long from snout to back, considerably smaller than the largest carcharodontosaurids like Carcharodontosaurus and Giganotosaurus, but still a large predator. This bone was also the first carcharodontosaurid skeletal fossil from anywhere in the world to be found in post-Turonian deposits.

Additionally, Azevedo et al. (2013) reported the proximal portion of a left fibula (Fig. 5d), which they assigned to a basal coelurosaurian theropod: an early-diverging member of the clade that would eventually go on to produce tyrannosauroids, dromaeosaurids, and birds, among other derived 
theropod species (e.g., Turner et al. 2012, Brusatte et al. 2014). If this referral is correct, it indicates that primitive coelurosaurs persisted in South America until very late in the Cretaceous, but it must be noted that coelurosaurs and some other theropods (such as noasaurids and neovenatorids) possessed very similar hindimbs that converged on each other in shape and proportion, so additional material is needed to confirm whether the Presidente Prudente specimen is genuinely a coelurosaur.

There are sauropods known from the Presidente Prudente Formation as well. The most important of these is a uniquely Brazilian taxon, Austroposeidon, which was named by Bandeira et al. (2016) based on portions of the neck, back, and sacrum. The authors estimated this dinosaur at about 25 meters in body length, making it, by far, the largest dinosaur yet discovered in Brazil, and considerably larger than the sauropods from the Adamantina Formation. Their phylogenetic analysis recovered Austroposeidon as a primitive titanosaur-one of the earliest-diverging lineages of this great sauropod dynasty, only very distantly related to the smaller aeolosaurins.

Marília Formation: The youngest unit of the Bauru Group, the Marília Formation, has yielded a wealth of dinosaur fossils, many of which have been found at Peirópolis, near the town of Uberaba in Minas Gerais State. All of the Marília dinosaur fossils belong to sauropods and theropods.

Three titanosaurian sauropods have been named based on specimens from the Marília Formation (Fig. 4). These are: Baurutitan, represented by a sacral vertebra and a series of 18 caudal vertebrae (Kellner et al. 2005) (Fig. 4d); Trigonosaurus, known from two specimens described by Campos et al. (2005) that together preserve large portions of the vertebral column; and Uberabatitan, described from three partial skeletons recovered from the same site, which suggests that the individuals were killed and buried together in a mass mortality event (Salgado and Carvalho 2008) (Fig. 4c). The phylogenetic relationships of these sauropods are currently unclear, as there has been little work in attempting to place them on the sauropod family tree. One recent analysis found Baurutitan to be a fairly derived titanosaur in a polytomy with the lineages that led to Saltasauridae and Aeolosaurini, meaning that it is plausible that it could belong to either of those characteristic South American clades (França et al. 2016). However, another recent study by Bandeira et al. (2016) recovered Baurutitan in a much more basal position, far removed from the aeolosaurins and as sister taxon to the mid Cretaceous Drusilasaura from Argentina. This latter analysis also found Uberabatitan within Saltasauridae (as the sister taxon to Brasilotitan), but Trigonosaurus in a more primitive position, in a small clade with Tapuiasaurus from the Early Cretaceous of Brazil and the putative aeolosaurin Maxakalisaurus (see above). This small clade is an intermediate subgroup of titanosaurs, immediately outside the clade of saltasaurids and aeolosaurins.

In addition to these named sauropod taxa, there are also several fragmentary titanosaurian specimens from the Marília Formation. These include an isolated caudal vertebra of an indeterminate aeolosaurin (Santucci and Bertini 2001, Martinelli et al. 2011, Filippi et al. 2013) and other putative aeolosaurin material (Lopes and Buchmann 2008, Martinelli et al. 2011), fragmentary cranial bones that appear most similar to derived lithostrotian titanosaurs (Martinelli et al. 2015), and several specimens belonging to indeterminate titanosaurs (e.g., Campos and Kellner 1999, Santucci and Bertini 2001, Marinho and Candeiro 2005, Martinelli et al. 2015).

The theropod record of the Marília Formation is substantially less complete than the sauropod record, as it consists entirely of isolated bones and teeth. Regardless, this fragmentary material can be assigned to a number of different groups, indicating a diverse theropod fauna. Numerous teeth have been assigned to abelisaurids and 
carcharodontosaurids (e.g., Kellner and Campos 2000, Candeiro 2002, 2007, 2009, Candeiro and Martinelli 2005, Candeiro et al. 2006a, b, 2012c, Candeiro and Tanke 2008, Novas et al. 2008). Furthermore, there are limited skeletal fossils of these large theropods. Novas et al. (2008) described a dorsal vertebra, distal femur (Fig. 5a), and pedal phalanx that belong to different abelisaurid individuals. The femur has a transverse dimension of over $100 \mathrm{~mm}$ at its distal end, which based on comparisons to more complete abelisaurids from other parts of the world indicates that this individual was about 3-4 meters in total length, roughly the size of the Argentine Xenotarsosaurus. A slightly smaller abelisaurid, represented by a beautifully preserved right tibia, was announced by Machado et al. (2013b). Most recently, Méndez et al. (2014) described additional abelisaurid postcranial material (a partial axis, partial pelvis, and fibula) from the Marília Formation and the São José do Rio Preto Formation, another putative Maastrichtian unit that crops out nearby in São Paulo State, but whose stratigraphic relationships to the Marília Formation are still somewhat unclear.

Some isolated specimens indicate the presence of other, smaller theropods in the Marília Formation. These include a thin and highly curved manual ungual that belongs to a small maniraptoran (Novas et al. 2005) (Fig. 5e) and a slender scapula that has also been referred to an indeterminate maniraptoran (Machado et al. 2008). Méndez et al. (2012) described an isolated caudal vertebra from the São José do Rio Preto Formation and referred it to Megaraptora, a group of lightly-built, fast-running, big-armed predators that are likely closely related to carcharodontosaurids (Benson et al. 2010), although they have also been suggested to be basal coelurosaurs or even close tyrannosauroid relatives (e.g., Novas et al. 2013). Finally, Candeiro et al. (2012a) described a small sample of avian fossils, including a metatarsal assigned to Enantiornithes, an extinct group of primitive birds that thrived in the Cretaceous (Fig. 5g-h).

\section{IMPLICATIONS OF THE BRAZILIAN RECORD}

As more fossils are discovered in Bauru Group sediments, one overarching pattern is coming into focus: there was a diverse dinosaur fauna in this part of South America during the final ca. 15-20 million years of the Mesozoic. These dinosaurs included several types of carnivores, herbivores, and potentially omnivorous species, ranging in size from tiny theropods that were probably less than a meter long to enormous sauropods approaching the length of passenger jets. A core set of taxa are common to most of the unequivocally latest Cretaceous (latest Santonian-Maastrichtian) aged formations of the Bauru Group: titanosaurian sauropods and abelisaurid and carcharodontosaurid theropods. Additionally, the fossils of small unenlagiine dromaeosaurids, indeterminate smallbodied maniraptorans, and birds have also been reported. Taken together, these specimens reveal a healthy diversity of dinosaurs at the tail end of the Cretaceous.

One unit of the Bauru Group in particular, the Marília Formation, gives insight into some of the last-surviving dinosaurs in South America, and possibly in Gondwana as a whole. This formation is dated as Maastrichtian based on microfossil and vertebrate biostratigraphy, meaning that it records a portion of the final $\sim 6$ million years of dinosaur evolution. Unfortunately, it is not possible to refine the age of this formation with more precision at this time, but even at the current limit of age resolution it is significant to have a confidently dated Maastrichtian unit that preserves a variety of dinosaur fossils. These specimens indicate that abelisaurids, carcharodontosaurids, some smaller maniraptoran theropods, and a variety of titanosaurs were still present in Brazil during the run-up to the end-Cretaceous asteroid impact. 
Given that the Marília dinosaurs are represented by mostly isolated and fragmentary fossils that have been the subject of much less collection effort than roughly contemporaneous latest Cretaceous faunas from the northern continents, this diversity of specimens speaks to a considerable richness of dinosaurs during the final stanza of their evolution.

These Bauru Group dinosaurs, most importantly those from the Marília Formation, can be compared to similar-aged records from elsewhere around the world, in order to gauge whether there may have been common patterns of latest Cretaceous dinosaur evolution before the extinction of the non-avian species. These comparisons are particularly informative because the Bauru dinosaurs were living in an inland part of Gondwana, whereas other key latest Cretaceous dinosaur faunas are predominantly known from coastal areas (either coastal plains, such as the Hell Creek and similar-aged faunas of North America, or small-to-mid-sized islands, like the latest Cretaceous European faunas of Spain and Romania).

The best-studied terminal Cretaceous faunas come from the western interior of North America, which boasts a series of fossil-rich CampanianMaastrichtian units extending to the CretaceousPaleogene boundary, which are stacked in stratigraphic order and in many cases confidently dated with radioisotopic data (Weishampel et al. 2004, Roberts et al. 2005, Eberth et al. 2013). The fossils from these units illustrate a coastal plain dinosaur fauna that underwent some general longterm turnover over the ca. 15 million years of the end Cretaceous, including declines in the diversity of some large-bodied plant-eaters at the base of the food chain, but which still included a diversity of carnivorous, herbivorous, and omnivorous species of varying body size up to the end of the Cretaceous (e.g., Fastovsky et al. 2004, Brusatte et al. 2012, 2015a). One particularly well-known North American unit, the Maastrichtian-age Hell
Creek Formation, captures the final $\sim 1.5$ million years of dinosaur evolution leading right up to the asteroid impact (Hartman et al. 2002, Fastovsky and Bercovici 2016). Systematic study of this formation has shown that dinosaurs remained abundant and diverse up until the very end of the Cretaceous, with no evidence of any local declines prior to the impact (Sheehan et al. 1991, Pearson et al. 2001, 2002, Fastovsky and Sheehan 2005).

The same situation appears to be the case in Europe, based on the ever-improving fossil record of Spain (Riera et al. 2009, Vila et al. 2013, 2016) and Romania (Csiki-Sava et al. 2016b). Although Europe had a very different paleogeography at the time - it was divided into a series of islands by high sea levels, unlike the continental coastal plain settings inhabited by the North American dinosaurs of end Cretaceous - it also shows evidence for some minor turnover events in the latest Cretaceous, but no clear long-term declines in dinosaur diversity and a rich fauna of carnivorous and herbivorous species during the last few million years before the asteroid impact (Csiki-Sava et al. 2015).

In its most general aspects, therefore, the Bauru Group corroborates the overarching story of latest Cretaceous dinosaur evolution that is emerging from the better-sampled, more nearshore northern continent faunas. There were diverse dinosaur faunas in Brazil during the last 15-20 million years of the Cretaceous, and a variety of different dinosaurs remained during the final stage of the period, the Maastrichtian, before the asteroid hit. Coupled with limited data from other latest Cretaceous aged units in Argentina, India and Madagascar (e.g., Weishampel et al. 2004, Sampson and Krause 2007, Novas 2009), this suggests that southern dinosaurs were still thriving - or at the very least, that several major subgroups were still in prominent positions in their ecosystems - towards the end of the Cretaceous. Like their northern counterparts, it seems as if these southern dinosaurs experienced a sudden extinction 
that was most likely due to the asteroid, although the influence of the Deccan eruptions cannot be completely ruled out (Brusatte et al. 2015a).

With that said, the Bauru Group dinosaurs do exhibitsomekey differences with the end-Cretaceous northern faunas (e.g., Weishampel et al. 2004). Most notably, the Brazilian record is dominated by titanosaurs, abelisaurids, and carcharodontosaurids, with only limited records of small theropods and, at least based on current evidence, no sign of smallto-mid-sized non-sauropod herbivores. In North America, on the other hand, the top predator faunas were much different. Only a single group of largebodied theropods, the tyrannosauroids, were at the top of the food chain, rather than the duo of abelisaurids and carcharodontosaurids in Brazil. Furthermore, in North America, sauropods were rare and even absent in some environments (such as the Hell Creek), small-to-mid-sized theropods like ornithomimosaurs and oviraptorosaurs were common, and there was a diversity of duck-billed hadrosaurs and horned ceratopsians filling the midto-large-sized herbivore niches. On the European islands there was a variety of titanosaurs and some abelisaurids, similar to Brazil and unlike North America. However, there was also a diversity of smaller predators and omnivores, and of duckbilled dinosaurs, quite distinctive from Brazil.

The rarity of small predatory and omnivorous dinosaurs in Brazil, compared to the situation in the north, is noteworthy. This could be an artefact of sampling: perhaps these small dinosaurs were not easily preserved, or have been more difficult to collect. However, there are numerous records of small-to-mid-sized crocodylomorphs from the latest Cretaceous of Brazil (e.g., Carvalho and Bertini 1999, Carvalho et al. 2005, Nobre and Carvalho 2006, Marinho and Carvalho 2009), and Gondwana in general, which raises doubt about any large-scale bias against preserving or collecting small vertebrates. Instead, it may be that crocodylomorphs were filling many of the same niches as small-to-mid-sized theropods in the north, where crocodylomorphs were much less diverse (e.g., Azevedo et al. 2013). Similarly, the lack of hadrosaurs or closely related mid-sized herbivores in Brazil probably means these dinosaurs were rare or even absent in this part of South America (although they were present in parts of Argentina, which may indicate regional differences in South America or sampling biases obscuring the Brazilian record: Novas 2009). If genuine, the lack of hadrosaurs and close relatives may be related to the diversity of titanosaurs in Brazil: perhaps it was the sauropods, with their diversity of body sizes and possibly diets, which filled the mid-sized herbivore niches occupied by duck-billed dinosaurs in many northern environments.

These differences between northern and southern faunas reflect the paleogeographical separation of Laurasia and Gondwana at the end of the Cretaceous, which allowed distinctive (and in some cases endemic) faunas to arise in physically separated landmasses. End-Cretaceous faunas were so different in North America, Europe, and South America, and yet dinosaurs, in their local idiosyncrasies, remained diverse up until the end in all of these regions but then disappeared and are never found in post-Cretaceous sediments. In our view, this lends credence to the hypothesis that the dinosaur extinction was a sudden, global event most likely caused by the asteroid impact.

It is always a little misleading, however, to use the vernacular term 'dinosaur' in these discussions, because some dinosaurs did survive past the Cretaceous: birds. And the Brazilian record has one final twist that provides a clue to understanding what happened to birds at the end of the Cretaceous. A handful of small avian fossils have been found in the Marília Formation, including material belonging to enantiornithines, a group of primitive birds that thrived in the Cretaceous but did not make it into the Paleogene (Candeiro et al. 2012a). As in North America (Longrich et al. 2011), it appears as if 
these birds persisted to the end of the Cretaceous in Brazil but then expired in the same global firestorm that knocked out most of the dinosaurs, but spared a few lineages of the more advanced, better flying, faster growing, seed-eating birds (e.g., Brusatte et al. 2015b, Larson et al. 2016), which went on to blossom into the $10,000+$ avian species still alive today.

\section{CHALLENGES AND FUTURE DIRECTIONS}

Our current understanding of the Bauru Group record indicates that dinosaurs were still diverse in the latest Cretaceous, including into the Maastrichtian. We can be confident that, at the very least, several major dinosaur subgroups survived into the last $\sim 6$ million years of the Cretaceous in Brazil, and were apparently still quite abundant and filled many roles in their ecosystems. But we acknowledge that this is a coarse-grained pattern, and much more work is needed to untangle exactly how dinosaur diversity was changing in the latest Cretaceous of Brazil (and Gondwana more broadly), and at what pace. We therefore identify the following as critical research objectives for the next decade:

1) More and better dinosaur fossils from the Bauru Group, particularly the terminal Cretaceous Marília Formation as well as the Adamantina and Presidente Prudente formations, are needed. Although many partial skeletons preserving articulated bones have been found over the last two decades, the vast majority of dinosaur fossils are isolated teeth and fragmentary bones. Perhaps surprisingly, only three dinosaur taxa from the Marília Formation have been identified to the species level, all titanosaurs. Increased focus on fieldwork, especially in underexplored areas of Goiás, Mato Grosso, and Mato Grosso do Sul states, will hopefully yield additional, and more complete, specimens that give better insight into the anatomy, biology, behaviors, diets, niches, and phylogenetic relationships of the final dinosaurs of Brazil.

2) We still need a better handle on the absolute ages of the Bauru Group formations, as well as their stratigraphic relationships across the huge expanse of the Paraná sedimentary basin. Radioisotopic dates would be groundbreaking, and could potentially clarify the timeline of dinosaur evolution in the Bauru Group just like they have in parts of western North America. Such dates are the best hope for determining the position of the last dinosaur fossils of Brazil relative to the K-Pg boundary. If the necessary igneous rocks are not available for dating, however, magnetostratigraphy and sequence stratigraphy probably offer the best approaches for untangling the correlations and relative positions of the Bauru Group formations. These could also help identify the placement of the very last-surviving dinosaur faunas, although with less accuracy and precision than radioisotopic dates. Magnetostratigraphy has been very successfully used to piece together a timeline of dinosaur evolution in western North America, and more recently in Spain, and we suggest that it should be a major focus of worker effort in Brazil. Additionally, further field-level stratigraphic and lithological work is needed, to better determine the correlations between units in what is seemingly a complex system of meandering rivers that migrated across the Bauru basin over time.

3) With more fossils and a better grasp of the ages and relationships of the formations they are found in, more rigorous statistical studies of dinosaur diversity change will become possible. These have been hugely successful in western North America (e.g., Sheehan et al. 1991, Pearson et al. 2001, 2002, Fastovsky et al. 2004, Fastovsky and Sheehan 2005, Campione and Evans 2011, Brusatte et al. 
2012, 2015a, Larson et al. 2016) and Spain (e.g., Vila et al. 2016), and are currently in progress in Romania (e.g., Csiki-Sava et al. 2016b). Only through detailed, layer-by-layer sampling, constrained by a robust timescale, can changes in diversity, abundance, and evolutionary rates be calculated over time. We suspect that, when they become feasible, these studies will demonstrate that there were no marked changes in dinosaur diversity during the latest Cretaceous of Brazil, during the final $\sim 15-20$ million years before the asteroid impact. However, our prediction may be incorrect, and these studies could potentially identify major faunal turnovers, changes in relative abundance or niche filling, or even declines in species richness, abundance, or evolutionary rates as the Cretaceous drew to a close. These quantitative macroevolutionary studies, therefore, will eventually reveal the true pattern of evolution during the final flourishing of dinosaurs in Brazil.

\section{ACKNOWLEDGMENTS}

Our collaborative project was funded by a grant from the Fundação de Amparo a Pesquisa de Goiás (FAPEG) and Newton Fund, which supported SLB's visit to Brazil to work with CRAC and FMS in June-July 2016. CRAC was partially supported by the Conselho Nacional de Ciência e Tecnologia by Produtividade e Pesquisa fellowship. SLB is also supported by a Marie Curie Career Integration Grant (CIG 630652). We thank the editor, Alexander Kellner, for the invitation to write this paper and Peter Sheehan and two anonymous reviewers for their helpful comments.

\section{REFERENCES}

ALVAREZ LW, ALVAREZ W, ASARO F AND MICHEL HV. 1980. Extraterrestrial cause for the CretaceousTertiary extinction. Science 208: 1095-1108.
ALVEŞ YM, BERGQVIST LP AND BRITO PM. 2016. New occurrences of microvertebrate Fossil accumulations in Bauru Group, Late Cretaceous of western São Paulo state, Brazil. J South Am Earth Sci 69: 80-90.

ARCHIBALD JD. 1996. Dinosaur Extinction and the End of an Era. Columbia University Press, New York.

ARCHIBALD JD AND FASTOVSKY DE. 2004. Dinosaur extinction. In: Weishampel DB, Dodson P and Osmólska $\mathrm{H}$ (Eds), The Dinosauria, $2^{\text {nd }}$ ed., Berkeley: University of California, p. 672-684.

AZEVEDO RPF AND SIMBRAS FM. 2009. New titanosaur sauropod remains from the Bauru Group (Late Cretaceous) of the Alfredo Marcondes Region, São Paulo State. Libro de Resúmenes. 24 ${ }^{\mathrm{a}}$ Jornadas Argentinas de Paleontología de Vertebrados (San Rafael), p. 15.

AZEVEDO RPF, SIMBRAS FM, FURTADO MR, CANDEIRO CRA AND BERGQVIST LP. 2013. First Brazilian carcharodontosaurid and other new theropod dinosaur fossils from the Campanian-Maastrichtian Presidente Prudente Formation, São Paulo State, southeastern Brazil. Cret Res 40: 1-12.

BANDEIRA KLN, SIMBRAS FM, MACHADO EB, CAMPOS DA, OLIVEIRA GR AND KELLNER AWA. 2016. A new giant Titanosauria (Dinosauria: Sauropoda) from the Late Cretaceous Bauru Group, Brazil. PLoS ONE 11(10): e0163373.

BARCELOS JH. 1984. Reconstrução paleogeográfica da sedimentação do Grupo Bauru baseada Na sua redefinição estratigráfica parcial em território paulista e no estudo preliminar fora do estado de São Paulo. PhD thesis. Universidade Estadual Paulista, Rio Claro, 190 p.

BARCELOS JH AND SUGUIO K. 1987. Correlação e extensão das unidades litoestratigráficas Do Grupo Bauru definida em território paulista, nos estados de Minas Gerais, Goiás, Mato Grosso do Sul e Paraná. Simp. Reg. Geol., 6. Rio Claro, 1987. Atas... Rio Claro, SBG/ Núcleo SP, 1, p. 313-332.

BATEZELLI A. 2010. Arcabouço tectono-estratigráfico e evolução das Bacias Caiuá e Bauru no Sudeste brasileiro. Rev Bras Geosci 40: 265-285.

BENSON RBJ, CAMPIONE NE, CARRANO MT, MANNION PD, SULLIVAN C, UPCHURCH P AND EVANS DC. 2014. Rates of dinosaur body mass evolution indicate 170 million years of sustained ecological innovation on the avian stem lineage. PLoS Biol 12(5): e1001853.

BENSON RBJ, CARRANO MT AND BRUSATTE SL. 2010. A new clade of archaic large-bodied predatory dinosaurs (Theropoda: Allosauroidea) that survived to the latest Mesozoic. Naturwiss 97: 71-78.

BERTINI RJ. 1996. Evidências de Abelisauridae (Carnosauria: Saurischia) do Neocretáceo da Bacia do Paraná. In: Simpósio sobre o Cretáceo do Brasil, 4, águas de São Pedro/Rio Claro, Boletim, Rio Claro, UNESP, p. 267-271. 
BERTINI RJ, MARSHALL LG, GAYET M AND BRITO P. 1993. Vertebrate faunas from the Adamantina and Marília (Upper Bauru Group, Late Cretaceous, Brazil) in their stratigraphic and paleobiogeographic context. $\mathrm{N}$ Jahrb Geol Paläont M 188(1): 71-101.

BITTENCOURT JS AND LANGER MC. 2011. Mesozoic dinosaurs from Brazil and their biogeographic implications. An Acad Bras Cienc 83: 23-60.

BRUM AS, MACHADO EB, CAMPOS DA AND KELLNER AWA. 2016. Morphology and internal structure of two new abelisaurid remains (Theropoda, Dinosauria) from the Adamantina Formation (TuronianMaastrichtian), Bauru Group, Paraná Basin, Brazil. Cret Res 60: 287-296.

BRUSATTE SL ET AL. 2015a. The extinction of the dinosaurs. Biol Rev 90: 628-642.

BRUSATTE SL, BUTLER RJ, PRIETO-MARQUEZ AAND NORELL MA. 2012. Dinosaur morphological diversity and the end-Cretaceous extinction. Nat Commun 3: 804.

BRUSATTE SL, LLOYD GT, WANG SC AND NORELL MA. 2014. Gradual assembly of avian body plan culminated in rapid rates of evolution across the dinosaurbird transition. Curr Biol 24: 2386-2392.

BRUSATTE SL, O'CONNOR JK AND JARVIS ED. 2015b. The origin and diversification of birds. Curr Biol 25: R888-R898.

BRUSATTE SL AND SERENO PC. 2008. Phylogeny of Allosauroidea (Dinosauria: Theropoda): comparative analysis and resolution. J Syst Palaeontol 6: 155-182.

CALVO JO AND GONZÁLEZ-RIGA B. 2003. Rinconsaurus caudamirus gen. et sp. nov., a new titanosaurid (Dinosauria, Sauropoda) from the Late Cretaceous of Patagonia, Argentina. Rev Geol Chile 30(2): 333-353.

CAMPIONE NE AND EVANS DC. 2011. Cranial growth and variation in edmontosaurs (Dinosauria: Hadrosauridae): implications for latest Cretaceous megaherbivore diversity in North America. PLoS ONE 6(9): e25186.

CAMPOS DA AND KELLNER AWA. 1999. On some sauropod (Titanosauridae) pelves from the continental Cretaceous of Brazil. Nat Sci Mus Monogr 15: 143-166.

CAMPOS DA, KELLNER AWA, BERTINI RJ AND SANTUCCI RM. 2005. On a titanosaurid (Dinosauria,Sauropoda) vertebral column from the Bauru Group, Late Cretaceous of Brazil. Arq Mus Nac 63: 565-593.

CANDE SC AND KENT DV 1995. Revised calibration of the geomagnetic polarity timescale for The Late Cretaceous and Cenozoic. J Geophys Res 100: 6093-6095.

CANDEIRO CRA. 2002. Dentes de Theropoda da Formação Marília (Santoniano-Maastrichtiano), Bacia Bauru, Região de Peirópolis, Uberaba, Minas Gerais, Brazil. Master's thesis, Universidade Federal do Rio de Janeiro, Brasil, 136 p. (Unpublished).
CANDEIRO CRA. 2007. Padrões morfológicos dos dentes de Abelisauroidea e Carcharodontosauridae (Theropoda, Dinosauria) do Cretáceo da América do Sul. PhD thesis. Universidade Federal do Rio de Janeiro, Brasil, 237 p.

CANDEIRO CRA 2009. Vertebrates of the Marília Formation (Late Maastrichtian) from the Peiropólis Paleontological Site: toward a better understanding. Earth Sci Res J 13(1): 6-15.

CANDEIRO CRA, ABRANCHES CT, ABRANTES EA, AVILLA LS, MARTINS VC, MOREIRA A, TORRES S AND BERGQVIST LP. 2004. Dinosaurs remains from western São Paulo state, Brazil (Bauru Basin, Adamantina Formation, Upper Cretaceous). J S Am Earth Sci 18: 1-10.

CANDEIRO CRA, AGNOLIN F, MARTINELLI AG AND BUCKUP PA. 2012a. First birds remains from the Upper Cretaceous of the Peirópolis site, Minas Gerais state, Brazil. Geodiv 34: 617-624.

CANDEIRO CRA, CAU A, FANTI F, NAVA W, AND NOVAS FE. 2012b. First evidence of An unenlagiid (Dinosauria, Theropoda, Maniraptora) from the Bauru Group, Brazil. Cret Res 37: 223-226.

CANDEIRO CRA, CURRIE PJ AND BERGQVIST LP. 2012c. Theropod teeth from the Marília Formation (late Maastrichtian) at the paleontological site of Peirópolis in Minas Gerais State, Brazil. Rev Bras Geo 42: 323-330.

CANDEIRO CRA AND MARTINELLI AG. 2005. Abelisauroidea and Carcharodontosauridae (Theropoda, Dinosauria) in the Cretaceous of South America. Paleogeographical and geochronological implications. Soc Nat Uber 17(33): 5-19.

CANDEIRO CRA, MARTINELLI AG, AVILLA LS AND RICH TH. 2006a. Tetrapods from the Upper Cretaceous (Turonian-Maastrichtian) Bauru Group of Brazil: a reappraisal. Cretaceous Res 27: 923-946.

CANDEIRO CRA AND RICH T. 2010. Overview of the Late Cretaceous Biota of the western São Paulo State, Brazil, Bauru Group. J South Am Earth Sci 29: 346-353.

CANDEIRO CRA, SANTOS AR, RICH TH, MARINHO TS AND OLIVEIRA EC. 2006b. Vertebrate fossils from the Adamantina Formation (Late Cretaceous), Prata paleontological district, Minas Gerais State, Brazil. Geobios 39: 319-327.

CANDEIRO CRA AND TANKE DH. 2008. A pathological Late Cretaceous carcharodontosaurid Tooth from Minas Gerais, Brazil. Bull Geosci 83: 351-354.

CARVALHO IS AND BERTINI RJ. 1999. Mariliasuchus, um novo Crocodylomorpha (Notosuchia) do Cretáceo da Bacia Bauru, Brasil. Rev Geol Colom 24: 83-105.

CARVALHO IS, CAMPOS ACA AND NOBRE PH. 2005. Baurusuchus salgadoensis, a new Crocodylomorpha from the Bauru Basin (Cretaceous), Brazil. Gond Res 8: 11-30.

CASTRO JC, DIAS-BRITO D, MUSACCHIO EA, SUÁREZ JM, MARANHÃO MSAS AND 
RODRIGUES R. 1999. Arcabouço estratigráfico do Grupo Bauru no Oeste Paulista. Boletim do 5u. Simpósio sobre o Cretáceo do Brasil / 1er Simpósio sobre el Cretácico de América del Sur, Rio Claro, Universidade Estadual Paulista 1999: 509-515.

COIMBRA AM. 1991. Sistematização crítica da obra. Livre-Docência thesis. Universidade de São Paulo. (Unpublished).

CSIKI-SAVA Z, BRUSATTE SL AND VASILE Ş. 2016a. "Megalosaurus cf. superbus" from Southeastern Romania: the oldest known Cretaceous carcharodontosaurid (Dinosauria: Theropoda) and its implications for earliest Cretaceous Europe-Gondwana connections. Cret Res 60: 221-238.

CSIKI-SAVA Z, BUFFETAUT E, ÖSI A, PEREDASUBERBIOLA X, BRUSATTE SL. 2015. Island life in the Cretaceous - faunal composition, biogeography, evolution, and extinction of land-living vertebrates on the Late Cretaceous European archipelago. ZooKeys 469: 1-161.

CSIKI-SAVA Z, VREMIR M, VASILE Ş, BRUSATTE SL, DYKE G, NAISH D, NORELL MA AND TOTOIANU R. 2016b. The East Side Story - the Transylvanian latest Cretaceous continental vertebrate record and its implications for understanding Creatceous-Paleogene Boundary events. Cret Res 57: 662-698.

DIAS-BRITO D, MUSACCHIO EA, CASTRO JC, MARANHÃO MSAS, SUAREZ JM AND RODRIGUES R. 2001. Grupo Bauru: uma unidade continental do Cretáceo no Brasil - concepções baseadas em dados micropaleontológicos, isotópicos e estratigráficos. Rev Paleobiol 20(1): 245-304.

EBERTH DA, EVANS DC, BRINKMAN DB, THERRIEN F, TANKE DH AND RUSSELL LS. 2013. Dinosaur biostratigraphy of the Edmonton Group (Upper Cretaceous), Alberta, Canada: evidence for climate influence. Can J Earth Sci 50: 701-726.

ERNESTO M, BATEZELLI A, SAAD AR, ETCHEBEHERE MLC AND FULFARO VJ. 2006. Início da Sedimentação Suprabasáltica na Bacia do Paraná: Paleomagnetismo do Grupo Caiuá (Oeste de São Paulo e Noroeste do Paraná). In: Simpósio Sobre o Cretáceo do Brasil, 7 e Simpósio do Terciário do Brasil, 1, Serra Negra, Boletim, p. 48.

FASTOVSKY DE AND BERCOVICI A. 2016. The Hell Creek Formation and its contribution to The CretaceousPaleogene extinction: A short primer. Cret Res 57: 368390.

FASTOVSKY DE, HUANG Y, HSU J, MARTINMCNAUGHTON J, SHEEHAN PM AND WEISHAMPEL DB. 2004. Shape of Mesozoic dinosaur richness. Geology 32: 877-880.

FASTOVSKY DE AND SHEEHAN PM. 2005. The extinction of the dinosaurs in North America. GSA Today 15: 4-10.
FERNANDES LA AND COIMBRA AM. 1996. A Bacia Bauru (Cretáceo Superior, Brasil). An Acad Bras Cienc 68: 195-205.

FERNANDES LA AND COIMBRA AM. 2000. Revisão estratigráfica da parte oriental da Bacia Bauru (Neocretáceo). Rev Bras Geoci 30: 717-728.

FERNANDES LAAND RIBEIRO CMM. 2015. Evolution and palaeoenvironment of the Bauru Basin (Upper Cretaceous, Brazil). J South Am Earth Sci 61: 71-90.

FILIPPI LS, MARTINELLI AG AND GARRIDO AC. 2013. Registro de un dinosaurio Aeolosaurini (Sauropoda, Titanosauria) en el Cretácico Superior (Formación Plottier) del Norte de la Provincia de Neuquén, Argentina, y comentarios sobre los Aeolosaurini sudamericanos. Rev Bras Paleontol 16(1): 147-156.

FRANÇA MAG, MARSOLA JCA, RIFF D, HSIOU AS AND LANGER MC. 2016. New lower jaw and teeth referred to Maxakalisaurus topai (Titanosauria: Aeolosaurini) and their implications for the phylogeny of titanosaurid sauropods. PeerJ 4: e2054.

FRANCO-ROSAS AC, SALGADO L, ROSAS CF AND CARVALHO IS. 2004. Nuevos materiales de titanosaurios (Sauropoda) en el Cretácico Superior de Mato Grosso, Brasil. Rev Bras Paleontol 7: 329-336.

FULFARO VJ AND BARCELOS JH. 1991. Grupo Bauru no Triângulo Mineiro: uma nova Visão litoestratigráfica. SBG/SP-RJ, Simpósio de Geologia do Sudeste, 2, São Paulo. Atas, p. 59-66.

FURTADO MR, CANDEIRO CRAAND BERGQVIST LP. 2013. Teeth of Abelisauridae and Carcharodontosauridae cf. (Theropoda, Dinosauria) form the CampanianMaastrichtian Presidente Prudente formation (southwestern São Paulo state, Brazil). Estud Geol 69(1): 105-114.

GOBBO-RODRIGUES SR, PETRI S AND BERTINI RJ. 1999. Ocorrências de Ostrácodes na Formação Adamantina do Grupo Bauru, Cretáceo Superior da Bacia do Paraná e possibilidades de correlação com depósitos isócronos argentinos. Parte I - Família Ilyocyprididae. Acta Geol Leopoldensia 23: 3-13.

GRILLO ON AND DELCOURT R. 2017. Allometry and body length of abelisauroid theropods: Pycnonemosaurus nevesi is the new king. Cret Res 69: 71-89.

HARTMAN JH, JOHNSON KR AND NICHOLS DJ. 2002. The Hell Creek Formation and The Cretaceous-Tertiary boundary in the northern Great Plains: an integrated continental record of the end of the Cretaceous. Geol Soc Am Spec Pap 361.

HASUI Y. 1969. O Cretáceo em Minas Gerais. Bol Soc Bras Geologia/São Paulo 18: 27-31.

HE HY, PAN YX, TAUXE L, QIN HF AND ZHU RX. 2008. Toward age determination of the M0r (Barremian-Aptian boundary) of the Early Cretaceous. Phys Earth Planet Int 169: 41-48. 
HUENE F VON. 1927. Contribuicion a la paleogeografia de SudAmerica-II. Las relaciones paleogeograficas de Sud America durante el Cretaceo Superior. Bol Acad Nac Cien 30: 256-294.

HUENE F VON. 1929. Los saurisquios y ornitisquios del Cretáceo Argentino. Ann Mus La Plata 3(2): 1-194.

HUENE F VON. 1939. Carta de F. von Huene ao Dr. Euzébio de Oliveira. Mineração e Metalurgia 4: 190.

KELLNER AWA AND AZEVEDO SAK. 1999. A new sauropod dinosaur (Titanosauria) from the Late Cretaceous of Brazil. Nat Sci Mus Monogr 15: 111-142.

KELLNER AWA AND CAMPOS DA. 2000. Brief review of dinosaur studies and perspectives in Brazil. An Acad Bras Cienc 72: 509-538.

KELLNER AWA AND CAMPOS DA. 2002. On a theropod dinosaur (Abelisauria) from the continental Cretaceous of Brazil. Arq Mus Nac 60: 163-170.

KELLNER AWA, CAMPOS DA, AZEVEDO SAK, TROTTA MNF, HENRIQUES DDR, CRAIK MMT AND SILVA HP. 2006. On a new titanosaur sauropod from the Bauru Group, Late Cretaceous of Brazil. Bol Mus Nac Geol 74: 1-31.

KELLNER AWA, CAMPOS DA AND TROTTA MNF. 2005. Description of a titanosaurid caudal series from the Bauru Group, Late Cretaceous of Brazil. Arq Mus Nac 63: 529-564.

LARSON DW, BROWN CM AND EVANS DC. 2016. Dental disparity and ecological stability in bird-like dinosaurs prior to the end-Cretaceous mass extinction. Curr Biol 26(10): 1325-1333.

LONGRICH NR, TOKARYK TT AND FIELD DJ. 2011. Mass extinction of birds at the Cretaceous-Paleogene (K$\mathrm{Pg}$ ) boundary. Proc Nat Acad Sci USA 108: 15253-15257.

LOPES RP AND BUCHMANN FSC. 2008. Fossils of titanosaurs (Dinosauria, Sauropoda) from a new outcrop in Triângulo Mineiro, southeastern Brazil. Rev Bras Paleontol 11: 69-72.

MACHADO EB, AVILLA LS, NAVA WR, CAMPOS DA AND KELLNER AWA. 2013a. A new titanosaur sauropod from the Late Cretaceous of Brazil. Zootaxa 3701(3): 301-321.

MACHADOEB, CAMPOS DA, CALVO JOAND KELLNER AWA. 2013b. A new abelisauroid from the Upper Cretaceous of Brazil. Rev Mex Cien Geol 30(2): 446-452.

MACHADO EB, CAMPOS DA AND KELLNER AWA. 2008. On a theropod scapula (Upper Cretaceous) from the Marília Formation, Bauru Group, Brazil. Paläontol Z 82: 308-313.

MACLEOD N ET AL. 1997. The Cretaceous-Tertiary biotic transition. J Geol Soc Lond 154: 265-292.

MARINHO TS AND CANDEIRO CRA. 2005. Titanosaur (Dinosauria: Sauropoda) osteoderms from the
Maastrichtian of Uberaba, Minas Gerais State, Brazil. Gondwana Res 8: 473-477.

MARINHO TS AND CARVALHO IS. 2009. An armadillolike sphagesaurid crocodyliform from the Late Cretaceous of Brazil. J South Am Earth Sci 27: 36-41.

MARTINELLI AG, MARINHO TDS, FILIPPI LS, RIBEIRO LCB, FERRAZ MLF, CAVELLANI CL, AND TEIXEIRA VPA. 2015. Cranial bones and atlas of titanosaurs (Dinosauria, Sauropoda) from Late Cretaceous (Bauru Group) of Uberaba, Minas Gerais State, Brazil. J South Am Earth Sci 61: 164-170.

MARTINELLI AG, RIFF D AND LOPES RP. 2011. Discussion about the occurrence of the Genus Aeolosaurus Powell 1987 (Dinosauria, Titanosauria) in the Upper Cretaceous of Brazil. Gaea 7: 34-40.

MÉNDEZ AH, NOVAS FE AND IORI FV. 2012. First Record of Megaraptora (Theropoda,Neovenatoridae) from Brazil. Com Ren Pal 11: 251-256.

MÉNDEZ AH, NOVAS FE, AND IORI FV. 2014. New record of abelisauroid theropods from the Bauru Group (Upper Cretaceous), São Paulo State, Brazil. Rev Bras Paleontol 17(1): 23-32.

MOREIRA JLP, MADEIRA CV, GIL JA AND MACHADO MAP. 2007. Bacia de Santos. Bol Geo Petro 15(2): 531549.

NOBRE PH AND CARVALHO IS. 2006. Adamantinasuchus navae: A new Gondwanan Crocodylomorpha (Mesoeucrocodylia) from the Late Cretaceous of Brazil. Gond Res 10: 370-378.

NOVAS FE. 2009. The Age of Dinosaurs in South America. Bloomington: Indiana University Press, $452 \mathrm{p}$.

NOVAS FE, AGNOLÍN FL, EZCURRA MD, PORFIRI J AND CANALE JI. 2013. Evolution of the carnivorous during the Cretaceous: The evidence from Patagonia. Cret Res 45: 174-215.

NOVAS FE, CARVALHO ID, RIBEIRO LCB AND MENDEZ AH. 2008. First abelisaurid bone remains from the Maastrichtian Marília Formation, Bauru Basin, Brazil. Cret Res 29: 625-635.

NOVAS FE, RIBEIRO LCB AND CARVALHO IS. 2005. Maniraptoran theropod ungual from the Marilia Formation (Upper Cretaceous), Brazil. Rev Mus Arg Ci Nat 7: 31-36.

PAULA E SILVA F, KIANG CH AND CAETANO-CHANG MR. 2003. Perfis de Referência do Grupo Bauru (K) no Estado de São Paulo. Geociências 22: 21-32.

PAULA E SILVA F, KIANG CH AND CAETANO-CHANG MR. 2009. Sedimentation of the Cretaceous Bauru Group in São Paulo, Paraná Basin, Brazil. J South Am Earth Sci 28: 25-39.

PEARSON DA, SCHAEFER T, JOHNSON KR AND NICHOLS DJ. 2001. Palynologically calibrated vertebrate record from North Dakota consistent with 
abrupt dinosaur extinction at the Cretaceous-Tertiary boundary. Geology 29: 39-42.

PEARSON DA, SCHAEFER T, JOHNSON KR, NICHOLS DJ AND HUNTER JP. 2002. Vertebrate biostratigraphy of the Hell Creek Formation in southwestern North Dakota and northwestern South Dakota. Geol Soc Am Sp Pap 361: 145-167.

PEYERL D, CANDEIRO CRAC AND FIGUEIRÔA SFM. 2015. Trajectory and contribution of geoscientists (1906-1961) to dinosaur research in the Bauru Group (Cretaceous) in the Triângulo Mineiro region of Brazil. J South Am Earth Sci 61: 64-70.

RAYFIELD EJ, BARRETT PM AND MILNER AR. 2009. Utility and validity of Middle and Late Triassic 'land vertebrate faunachrons'. J Vert Paleontol 29(1): 80-87.

RIERA V, OMS O, GAETA R AND GALOBART A. 2009. The end-Cretaceous dinosaur succession in Europe: the Tremp Basin record (Spain). Palaeogeog Palaeoclim Palaeoecol 283: 160-171.

RICCOMINI C. 1997. Arcabouço estrutural e aspectos do tectonismo gerador e deformador daBacia Bauru no estado de São Paulo. Rev Bras Geoci 27(2): 153-162.

ROBERTS EM, DEINO A AND CHAN MA. 2005. 40Ar/39Ar age of the Kaiparowits Formation,southern Utah, and correlation of contemporaneous Campanian strata and faunas along the margin of the Western Interior Basin. Cret Res 26: 307-318.

SALGADO L AND CARVALHO IS. 2008. Uberabatitan ribeiroi, a new titanosaur from the Marília Formation (Bauru Group, Upper Cretaceous), Minas Gerais, Brazil. Palaeontology 51: 881-901.

SAMPSON SD AND KRAUSE DW. 2007. Majungasaurus crenatissimus (Theropoda: Abelisauridae) from the Late Cretaceous of Madagascar. Soc Vert Paleontol Mem 8: $1-184$.

SANTUCCI RM AND ARRUDA-CAMPOS ACD. 2011. A new sauropod (Macronaria, Titanosauria) from the Adamantina Formation, Bauru Group, Upper Cretaceous of Brazil and the phylogenetic relationships of Aeolosaurini. Zootaxa 3085: 1-33.

SANTUCCI RM AND BERTINI RJ. 2001. Paleogeographical and biochronological distributions of the Bauru Group titanosaurids (Saurischia, Sauropoda), Upper Cretaceous of southeastern Brazil. Rev Bras Geoci 31: 307-314.

SANTUCCI RM AND BERTINI RJ. 2006. A new titanosaur from western São Paulo State, Upper Cretaceous Bauru Group, South-East Brazil. Palaeontology 49: 59-66.

SCHULTE P ET AL. 2010. The Chicxulub asteroid impact and mass extinction at the Cretaceous-Paleogene boundary. Science 327: 1214-1218.
SHEEHAN PM, FASTOVSKY DE, HOFFMANN RG, BERGHAUS CB AND GABRIEL DL. 1991. Sudden extinction of the dinosaurs: family-level patterns of ecological diversity during the latest Cretaceous, upper Great Plains, USA. Science 254: 835-839.

SIMBRAS FM. 2009. Análise estratigráfica do intervalo superior do Grupo Bauru (Cretáceo Superior) na região de Alfredo Marcondes-SP. Undergradute thesis. Universidade Federal do Rio de Janeiro, p. 34. (Unpublished).

SOARES PC, LANDIM PMB, FULFARO VJ AND SOBRIERO NETO AF. 1980. Ensaio de Caracterização estratigráfica do Cretáceo no estado de São Paulo: Grupo Bauru. Rev Bras Geocienc 10: 177-185.

SOUZA JJ. 1984. O Grupo Baurú na porção mais setentrional da bacia sedimentar do Paraná. Anais do 33e Congresso Brasileiro de Geologia, Rio de Janeiro 2: 944-957.

SUGUIO KE AND BARCELOS JH. 1983. Calcretes of the Bauru Group (Cretaceous), Brazil: Petrology and geological significance. Bol Inst Geociência Univ São Paulo 5: 34-47.

TAMRAT E, ERNESTO M, FULFARO VJ, SAAD AR, BATEZELLI A AND OLIVEIRA AF. 2002. Magnetoestratigrafia das Formações Uberaba e Marília (Grupo Bauru) no Triângulo Mineiro. VI SIMPÓSIO SOBRE O CRETÁCEO BRASILEIRO E II SIMPÓSIO SOBRE EL CRETÁCICO DE AMERICA DEL SUR, São Pedro, p. 323-327.

TURNER AH, MAKOVICKY PJ AND NORELL MA. 2012. A review of dromaeosaurid systematics and paravian phylogeny. Bull Am Mus Nat Hist 371: 1-206.

VILA B, OMS O, FONDEVILLA V, GAETE R, GALOBART A, RIERA V AND CANUDO JI. 2013. The latest succession of dinosaur tracksites in Europe: hadrosaur ichnology, track production and palaeoenvironments. PLoS ONE 8(9): e72579.

VILA B, SELLES AG AND BRUSATTE SL. 2016. Diversity and faunal changes in the latest Cretaceous dinosaur communities of southwestern Europe. Cret Res 57: 552-564.

WEISHAMPEL DB, BARRETT PM, CORIA RA, LE LOEUFF J, XU X, ZHAO X, SAHNI A, GOMANI EMP AND NOTO CR. 2004. Dinosaur distribution. In: Weishampel DB, Dodson P and Osmólska H (Eds), The Dinosauria, $2^{\text {nd }}$ ed., Berkeley: University of California, $\mathrm{p}$. 517-606.

ZAHER H, POL D, CARVALHO AB, RICCOMINI C, CAMPOS D AND NAVA W. 2006. Redescription of the cranial morphology of Mariliasuchus amarali, and its phylogenetic affinities (Crocodyliformes, Notosuchia). Am Mus Novit 3512: 1-40. 